\title{
Pengaruh Daya Tarik Iklan E-commerce Terhadap Brand Trust Konsumen (Survei Terhadap Penonton Iklan Tokopedia \#MulaiAjaDulu di Youtube)
}

\author{
Fernaldo, Roswita Oktavianti \\ aldozudrajat@gmail.com,roswitao@fikom.untar.ac.id \\ Fakultas Ilmu Komunikasi Tarumanagara
}

\begin{abstract}
The appeal of advertising can be understood as something that moves people, talks about their wants or needs, and attracts their interests. The attractiveness of advertising is very important because it will increase the success of communication with consumers. An ad with a very high ad appeal can create brand trust. Brand trust is the customer's desire to rely on a brand that causes problems caused by brand expectations that will lead to positive results. This study aims to measure the effect of e-commerce on consumer brand trust. This research uses quantitative techniques with survey methods and uses Tokopedia as an observation unit. Primary data was collected through distributing questionnaires to 118 respondents who studied and watched Tokopedia \#MulaiAjaDulu advertisements and were domiciled in West Jakarta. Data analysis uses the Statistical Package for Social Sciences with the SPSS application for Windows 15. Based on the results of the study, it is known to be related to the attractiveness of e-commerce advertisements on Tokopedia consumer brand trust. The appeal of advertising has a 53.3\% effect on brand trust. If the attractiveness of advertising increases, consumer brand trust will also increase. If ad appeal decreases, consumer brand trust will also decrease.
\end{abstract}

Keywords: advertising appeal, brand trust, e-commerce, tokopedia

\begin{abstract}
Abstrak
Daya tarik iklan bisa diartikan sebagai suatu hal yang mendorong orang, berpendapat tentang kemauan atau keperluan mereka, dan merangsang ketertarikan mereka. Daya tarik iklan sungguh penting karena akan menaikkan keberhasilan komunikasi dengan pelanggan. Suatu iklan dengan daya tarik iklan yang tinggi dapat menciptakan kepercayaan akan suatu merek (brand trust). Brand trust adalah kemauan pelanggan untuk bergantung terhadap suatu merek dengan akibat-akibat yang dijumpai karena harapan kepada merek itu akan membuahkan efek yang positif. Penelitian ini bertujuan untuk mengukur pengaruh daya tarik iklan e-commerce terhadap brand trust konsumen. Penelitian ini menggunakan teknik kuantitatif dengan metode survei dan menggunakan Tokopedia sebagai unit observasi. Data primer dikumpulkan dengan cara menyebarkan kuesioner terhadap 118 responden yang mengetahui dan menonton iklan Tokopedia \#MulaiAjaDulu dan berdomisili di Jakarta Barat. Analisis data menggunakan Statistical Package for the Social Sciences dengan aplikasi SPSS for windows 15. Berdasarkan hasil penelitian, diketahui bahwa terdapat pengaruh positif antara daya tarik iklan e-commerce terhadap brand trust konsumen Tokopedia. Daya tarik
\end{abstract}


iklan memiliki pengaruh sebesar 53,3\% terhadap brand trust. Jika daya tarik iklan meningkat maka brand trust konsumen juga akan meningkat. Sebaliknya, jika daya tarik iklan menurun maka brand trust konsumen juga akan ikut menurun.

Kata kunci: brand trust, daya tarik iklan, e-commerce, tokopedia

\section{Pendahuluan}

Iklan kini menjadi bagian penting dalam suatu strategi pemasaran pada suatu perusahaan. Menurut Paramita Dewi, iklan adalah suatu pesan tentang brand, produk, atau perusahaan yang diteruskan kepada khalayak menggunakan media. Penentuan media pada periklanan harus dilaksanakan secara tepat, salah satunya menggunakan media internet. Menurut Ditya, dengan adanya internet dapat membantu efisiensi dan efektivitas perusahaan, yaitu sebagai media komunikasi, pengumuman, dan sarana untuk memperoleh informasi yang diperlukan oleh sebuah perusahaan (dalam Yuniyanto dan Sirine, 2018).

Perkembangan dalam membuat suatu iklan memiliki daya tarik yang khas dan sanggup memikat rasa ingin tahu bagi para khalayaknya. Morissan (2014) berpendapat bahwa daya tarik iklan adalah suatu hal yang menggerakan seseorang, berdiskusi tentang kemauan atau pun kebutuhan mereka dan merangsang ketertarikan mereka. Daya tarik iklan merujuk kepada pendekatan yang dipakai untuk merangsang perhatian konsumen dan/atau mempengaruhi emosi mereka tentang suatu produk (barang dan jasa) (Morissan, 2010). Secara teoritis, iklan yang memiliki daya tarik yang kuat adalah iklan yang mempunyai kriteria-kriteria yaitu, memiliki makna (meaningful), mengungkapkan manfaat atau guna yang membuat produk lebih bermanfaat atau menarik bagi konsumen, lalu dapat dipercaya oleh pelanggan (believable), daya tarik iklan harus terpercaya, dan berbeda (distinctive), pesan iklan lebih menarik dibandingkan kompetitornya (Kotler \& Armstrong, 2011). Suatu iklan juga harus menampilkan elemen merek di dalamnya, diantaranya nama merek, logo, slogan, dll (Oktavianti \& Utami, 2019).

Tidak seperti pada iklan di televisi, iklan di internet akan muncul terusmenerus tanpa dibatasi oleh waktu. Salah satu situs peron (platform) yang sering dikunjungi dan memuat banyak iklan adalah Youtube. Dalam jangka yang singkat akan ada banyak sekali iklan yang disaksikan oleh pengguna Youtube. Menurut Burgess \& Joshua Green (2011), YouTube adalah platform untuk dan aggregator konten, tapi bukan produsen konten itu sendiri. YouTube adalah salah satu situs media sosial yang paling banyak dikunjungi saat ini. Indriarto berpendapat bahwa iklan yang semakin besar jangkauan medianya dan frekuensi tayang yang semakin tinggi akan membuat khalayak semakin sering mengetahui dan memahami informasi iklan dan merasakan efek dari iklan itu sendiri (dalam Hastuti, 2013).

Suatu iklan dengan daya tarik iklan yang tinggi dapat menciptakan kepercayaan akan suatu merek yang tinggi pula. Lau dan Lee mengartikan kepercayaan merek (brand trust) adalah kemauan konsumen untuk berharap kepada suatu merek dengan akibat - akibat yang dijumpai karena harapan pada merek tersebut akan membuahkan efek yang positif (Tjahyadi, 2006). Menurut 
Fernaldo, Roswita Oktaviani: Pengaruh Daya Tarik Iklan E-commerce Terhadap Brand Trust Konsumen (Survei Terhadap Penonton Iklan Tokopedia \#MulaiAjaDulu di Youtube)

Kautonen dan Karjaluoto (dalam Quraini \& Saputri,2018), pengukuran brand trust terdiri atas dua bagian yaitu: Brand Reliability, pada dimensi ini, konsumen yakin jika produk/jasa dapat memenuhi nilai yang dijanjikannya. Kemudian, Brand Intention, konsumen memiliki keyakinan terhadap suatu merek apabila terjadi permasalahan yang muncul secara tidak terduga, merek tersebut akan menempatkan kepentingan konsumen menjadi hal yang utama.

Tokopedia merupakan perusahaan marketplace atau situs jual beli online yang membuat transaksi antara penjual dan pembeli berlangsung dengan aman. Tokopedia adalah salah satu situs jual beli online yang ternama dan sudah mencapai tahap unicorn. Pada awal tahun 2018, Tokopedia meluncurkan kampanye iklan \#MulaiAjaDulu. Kampanye yang diolah oleh agensi periklanan Flock itu mempunyai misi untuk mengingatkan khalayaknya bahwa mimpi dapat menjadi kenyataan, apabila kamu mau memulainya terlebih dahulu.

Berdasarkan penjelasan latar belakang tersebut, peneliti tertarik untuk melihat apakah ada pengaruh daya tarik iklan e-commerce terhadap brand trust konsumen.

\section{Metode Penelitian}

Dalam penelitian ini, peneliti menggunakan metode penelitian kuantitatif dengan pendekatan survei. Metode survei adalah penelitian yang dilaksanakan dengan cara mengumpulkan data atau informasi yang dilakukan dengan cara mengajukan daftar pertanyaan atau pernyataan kepada responden. Penggalian data dapat dilakukan melalui kuesioner dan wawancara (Sujarweni, 2014:8). Populasi merupakan kelompok yang memiliki nilai dan karakter tertentu yang ditetapkan oleh peneliti (Sugiyono, 2017:80). Populasi yang dipakai di dalam penelitian ini adalah masyarakat Jakarta Barat. Sampel merupakan bagian dari sejumlah yang dipunyai oleh populasi, jika populasi besar peneliti bisa memakai sampel yang diambil dari populasi itu sendiri (Sujarweni, 2019:65). Untuk menetapkan jumlah sampel minimum dalam penelitian ini, penulis memakai teori Roscoe dengan cara jumlah indikator dikali 5. Dalam penelitian ini, peneliti menyebarkan kuesioner kepada 118 responden masyarakat daerah Jakarta Barat yang menonton iklan Tokopedia \#MulaiAjaDulu di YouTube melalui google form untuk mendapatkan data sesuai dengan yang diharapkan oleh peneliti. Penelitian ini memakai teknik non probability, yaitu penarikan sampel yang tidak memberikan peluang atau kesempatan yang sama bagi seluruh anggota populasi untuk dijadikan sebagai sampel penelitian (Sujarweni, 2019:71). Dalam penelitian ini, peneliti memakai teknik nonprobability sampling dengan pendekatan purposive sampling. Penelitian ini diukur dengan skala likert menggunakan bantuan software SPSS ver. 15 untuk menguji validitas, reliabilitas, dan hipotesis.

\section{Hasil Penelitian dan Diskusi}

Dalam penelitian ini, peneliti menyebarkan kuesioner kepada sebanyak 118 responden dan mendapatkan data berupa jenis kelamin, sebanyak 48,3\% responden 
berjenis kelamin laki-laki dan sebanyak $51,7 \%$ responden sebanyak perempuan. Sedangkan secara usia, responden di dominasi pada usia 18 - 22 tahun sebanyak $75,4 \%$, kemudian 23 - 27 tahun sebanyak 17,8\%, lalu 28- 32 tahun sebanyak 2,5\%, dan 33-37 tahun sebanyak 4,2\%. Setelah melakukan uji validitas dengan menggunakan aplikasi SPSS for windows ver 15, maka berikut adalah hasil dari uji validitas.

Tabel 1. Uji Validitas

\begin{tabular}{|c|c|c|c|}
\hline triabel & Butir Indikator & $\begin{array}{c}\text { rected Item } \\
\text { Total } \\
\text { Correlation } \\
\end{array}$ & aterangan \\
\hline \multirow{12}{*}{$\begin{array}{l}\text { Tarik Iklan } \\
\text { (X) }\end{array}$} & & 0,695 & Valid \\
\hline & & 0,701 & Valid \\
\hline & & 0,715 & Valid \\
\hline & & 0,683 & Valid \\
\hline & & 0,601 & Valid \\
\hline & & 0,719 & Valid \\
\hline & & 0,604 & Valid \\
\hline & & 0,580 & Valid \\
\hline & & 0,525 & Valid \\
\hline & & 0,599 & Valid \\
\hline & & 0,476 & Valid \\
\hline & & 0,638 & Valid \\
\hline \multirow{10}{*}{$\begin{array}{l}\text { Brand } \\
\text { Trust } \\
\text { (Y) }\end{array}$} & BT 1 & 0,743 & Valid \\
\hline & BT 2 & 0,711 & Valid \\
\hline & BT 3 & 0,718 & Valid \\
\hline & BT 4 & 0,714 & Valid \\
\hline & BT 5 & 0,742 & Valid \\
\hline & BT 6 & 0,784 & Valid \\
\hline & BT 7 & 0,706 & Valid \\
\hline & BT 8 & 0,786 & Valid \\
\hline & BT 9 & 0,780 & Valid \\
\hline & BT 10 & 0,666 & Valid \\
\hline
\end{tabular}

Sumber: Hasil Pengolahan Data SPSS Ver 15

Tabel 1, menunjukkan bahwa butir-butir indikator pernyataan dari seluruh variabel dinyatakan valid seluruhnya karena memiliki angka korelasi di atas 0,2. 
Fernaldo, Roswita Oktaviani: Pengaruh Daya Tarik Iklan E-commerce Terhadap Brand Trust Konsumen (Survei Terhadap Penonton Iklan Tokopedia \#MulaiAjaDulu di Youtube)

Tabel 2. Uji Reliabilitas

\begin{tabular}{lcl}
\hline \multicolumn{1}{c}{ Variabel } & lai Cronbach's Alpha & Keterangan \\
\hline ya Tarik Iklan $(\mathrm{X})$ & 0,903 & Reliabel \\
\hline Brand Trust $(\mathrm{Y})$ & 0,931 & Reliabel \\
\hline
\end{tabular}

Sumber: Hasil Pengolahan Data SPSS Ver. 15

Tabel 2, menunjukkan bahwa setiap pernyataan dalam kuesioner dikatakan reliabel karena memiliki nilai Cronbach's Alpha diatas 0,6.

Tabel 3. Uji Normalitas

One-Sample Kolmogorov-Smirnov Test

\begin{tabular}{llrr}
\hline & & T.DT & \multicolumn{1}{c}{ T.BT } \\
N & & 118 & 118 \\
Normal & Mean & 39,48 & 50,41 \\
Parameters(a,b) & Std. Deviation & 5,803 & 6,173 \\
Most Extreme & Absolute &, 129 &, 147 \\
Differences & Positive &, 117 &, 111 \\
& Negative &,- 129 &,- 147 \\
Kolmogorov-Smirnov Z & 1,398 & 1,599 \\
Asymp. Sig. (2-tailed) &, 040 &, 012 \\
\hline a Test distribution is Normal. & & \\
b Calculated from data.
\end{tabular}

Sumber: Hasil Pengolahan Data SPSS Versi 15.0

Dalam penelitian ini, peneliti menggunakan uji One Sample Kolmogorov Smirnov yang ada pada aplikasi SPSS Ver 15. Hasil analisis pada tabel 3 menunjukan bahwa ada nilai signifikansi sebesar 0,040 untuk variabel $\mathrm{X}$ dan 0,012 untuk variabel Y. Hasil tersebut menyatakan bahwa distribusi data tidak berdistribusi secara normal karena nilai signifikansi $\mathrm{X}$ dan $\mathrm{Y}>0,05$.

Tabel 4. Hasil Uji T

\begin{tabular}{llllll}
\hline Model & \multicolumn{2}{l}{$\begin{array}{l}\text { istandardized } \\
\text { Coefficients }\end{array}$} & $\begin{array}{c}\text { indardized } \\
\text { Coefficients }\end{array}$ & t & ig. \\
\hline onstant) & B & Error & Beta & & \\
\hline Tarik Iklan & 1,719 & 536 & & 276 & 00 \\
\cline { 2 - 6 } &, 791 & 566 & 0,743 &, 973 & 000 \\
\hline
\end{tabular}

Sumber: Hasil Pengolahan Data SPSS Ver 15 
Tabel 4 menunjukkan dari hasil analisis data diketahui bahwa nilai $\mathrm{t}=11,973$ dan tingkat signifikansi $=0,00<0,05$. Karena nilai p lebih kecil dari 0,05 , maka $\mathrm{H}_{0}$ ditolak dan $\mathrm{H}_{\mathrm{a}}$ diterima, yang dapat disimpulkan terdapat pengaruh positif daya tarik iklan terhadap brand trust konsumen.

Tabel 5. Hasil Uji Regresi Linear Sederhana

\begin{tabular}{llllll}
\hline \multirow{2}{*}{ Model } & \multicolumn{2}{c}{$\begin{array}{c}\text { Instandardized } \\
\text { Coefficients }\end{array}$} & $\begin{array}{c}\text { tandardized } \\
\text { Coefficients }\end{array}$ & $\mathrm{t}$ & jig. \\
\cline { 2 - 6 } & $\mathrm{B}$ & l. Error & Beta & & \\
\hline (Constant) &, 719 & $\vdots, 636$ & & 7,276 &, 000 \\
\hline irand Trust & 791 & 1,066 & 0,743 & 1,973 &, 000 \\
\hline
\end{tabular}

Sumber: Hasil Pengolahan Data SPSS Ver 15

Dengan keterangan $\mathrm{Y}=$ Brand trust dan $\mathrm{X}=$ Daya Tarik Iklan. Berdasarkan persamaan regresi linear pada tabel 5, dapat dijabarkan sebagai berikut:

1. $\quad$ Nilai Y (Brand Trust) akan tetap sebesar 19,719 konstanta jika nilai X (Daya Tarik Iklan) tidak mengalami perubahan, baik peningkatan maupun penurunan.

2. Jika nilai $X$ (Daya Tarik Iklan) mengalami kenaikan nilai sebesar 1 satuan, maka nilai Y (Brand Trust) akan mengalami kenaikan sebesar 0,791 menjadi 20,510 .

Tabel 6. Hasil Uji Koefisien Korelasi

\begin{tabular}{ccccc}
\hline Model & 2 & Square & isted R Square & $\begin{array}{r}\text { Error of the } \\
\text { Estimate }\end{array}$ \\
\hline 1 & $\vdash 3 \mathrm{a}$ & .553 & .549 & 4,146 \\
\hline
\end{tabular}

Sumber: Hasil Pengolahan Data SPSS Ver 15

Dari hasil perhitungan tabel 6, didapati bahwa nilai koefisien korelasi R sebesar 0,743 yang berada di antara interval 0,60 - 0,799 artinya daya tarik iklan mempunyai hubungan yang kuat terhadap brand trust konsumen.

\section{Tabel 7. Hasil Uji Determinasi}

\begin{tabular}{lcccc}
\hline odel & 2 & Square & isted R Square & $\begin{array}{r}\text { Error of the } \\
\text { Estimate }\end{array}$ \\
\hline 1 & $13 \mathrm{a}$ & .553 & .549 & 4.146 \\
\hline
\end{tabular}

Sumber: Hasil Pengolahan Data SPSS Ver 15 
Fernaldo, Roswita Oktaviani: Pengaruh Daya Tarik Iklan E-commerce Terhadap Brand Trust Konsumen (Survei Terhadap Penonton Iklan Tokopedia \#MulaiAjaDulu di Youtube)

Dari hasil perhitungan tabel 7, didapati nilai pada tabel R Square sebesar 0,533 mengartikan bahwa 53,3\% brand trust dipengaruhi oleh daya tarik iklan sementara sisanya 46,7\% (100\%-53,3\%) dipengaruhi oleh faktor lain.

\section{Simpulan}

Penelitian ini menyimpulkan bahwa antara daya tarik iklan e-commerce dengan brand trust konsumen terdapat hubungan dengan hubungan yang kuat. Berdasarkan hasil uji koefisien korelasi, diketahui bahwa nilai korelasi berada di antara interval 0,60 - 0,799 yang menunjukkan bahwa daya tarik iklan memiliki pengaruh yang kuat terhadap brand trust konsumen dan bersifat positif. Dengan demikian, semakin meningkatnya daya tarik iklan maka brand trust juga akan meningkat. Sebaliknya bila daya tarik suatu iklan menurun maka brand trust oleh konsumen juga akan menurun.

Berdasarkan kuesioner yang telah disebarkan, data pernyataan sebanyak 22 butir pernyataan dinyatakan valid, karena semua pernyataan yang telah disebarkan mendukung pernyataan bahwa terdapat pengaruh antara daya tarik iklan e-commerce terhadap brand trust konsumen.

\section{Ucapan Terima Kasih}

Ucapan terima kasih diberikan Fakultas Ilmu Komunikasi Universitas Tarumanagara, Responden, Keluarga, Teman-teman, dan seluruh pihak yang membantu peneliti dalam menyempurnakan penelitian ini.

\section{Daftar Pustaka}

Burgess, Jean dan Green, Joshua. (2011). Youtube Digital Media and Society Series. Cambridge: MPG Books Group.

Hastuti, Sri. (2013). Efektivitas Iklan Layanan Masyarakat di Televisi. Jurnal Ilmu Komunikasi FISIP Universitas Riau Vol. 2 No. 2. 67 - 72.

Kotler, Philip dan Armstrong, Gary. (2011). Prinsip-Prinsip Pemasaran. Cetakan -

12. Jilid 1. Jakarta: Erlangga.

Morissan. (2010). Periklanan: Komunikasi Pemasaran Terpadu. Jakarta: Kencana.

Morissan. (2014). Periklanan: Komunikasi Pemasaran Terpadu. Jakarta: Kencana.

Oktavianti, Roswita dan Utami, Budi. (2019). Strategi Mempertahankan Brand Knowledge Program Televisi Seputar Indonesia di RCTI. Jurnal Komunikasi Volume 11 No. 1.81 - 91.

Sugiyono. (2017). Metode Penelitian Kuantitatif, Kualitatif, dan RdanD. Bandung: Alfabeta.

Tjahyadi, Rully Arlan. (2006). Brand Trust dalam Konteks Loyalitas Merek: Peran Karakteristik Merek, Karakteristik Perusahaan, dan Karakteristik Hubungan 
Pelanggan - Merek. Jurnal Manajemen Universitas Kristen Maranatha Vol. 6 No. $1.65-78$.

Yuniyanto, H.S. dan Sirine, H. (2018). Pengaruh Iklan terhadap Minat Beli Pengguna Youtube dengan Brand Recognition sebagai Variabel Intervening. Esensi Jurnal Bisnis dan Manajemen Volume 8 No. 1. 21 - 28. 